\title{
Penanaman Nilai-nilai Toleransi Beragama pada Pembelajaran Pendidikan Agama Islam (PAI)
}

\author{
Zulyadain \\ Universitas Islam Negeri (UIN) Mataram \\ zulyadain_07@yahoo.com
}

\begin{abstract}
Being tolerant is allowing others to be themselves, respecting others, respecting their origin and background. Tolerance invites dialogue to communicate the existence of mutual recognition. This is the picture of tolerance in its solid form. This article aims to find out the cultivation of religious tolerance values in the learning of Islamic Education (PAI). The results of the study indicate that the following measures are: first, schools should establish and implement local laws, for example school laws that are specifically applied in a particular school. Second, to build a sense of understanding from an early age between students who have different religious beliefs, the school must play an active role in promoting religious dialogue or interfaith dialogue which must remain in the guidance of teachers in the school. Third, another important thing in the application of the education of tolerance, the curriculum and textbooks used and applied in schools. Furthermore, the teaching model that can be an option for the cultivation of religious tolerance values in schools includes communicative teaching models and active teaching models.
\end{abstract}

Keywords: Tolerance, Early Childhood Education, PAI Learning, School Curriculum and Lesson Book. 


\section{Pendahuluan}

Di era global, plural, dan multikultural seperti sekarang setiap saat dapat saja terjadi peristiwa-peristiwa yang tidak dapat terbayangkan dan tidak terduga sama sekali. Selain membawa kemudahan dan kenyamanan hidup umat manusia, kemajuan ilmu dan teknologi juga membawa akibat pada melebarnya perbedaan tingkat pendapatan ekonomi antara negaranegara kaya dengan negara miskin. Alat transportasi yang semakin cepat dan canggih berdampak pada hilangnya jarak antara satu wilayah pemangku tradisi keagamaan tertentu dengan pemegang tradisi keagamaan yang lain. Kontak-kontak budaya semakin cepat dan pergesekan kultur serta tradisi tidak terhindarkan, yang bahkan tidak lagi mengenal batas-batas geografis secara konvensional. Internet, e-mail, faksimile, telepon, mobile phone, video, dan sebagainya menjadikan anak didik memperoleh pengetahuan lebih cepat dari gurunya.

Salah satu bentuk perubahan manusia yang bersifat global dan berhubungan dengan komunitas Muslim adalah perubahan perilaku dan fungsi lembaga keagamaan. Berbagai nilai yang tumbuh dan berkembang dari cara manusia merealisasi ajaran agamanya mulai dipertanyakan fungsinya dalam modernitas kehidupan masyarakat. Tidak dapat ditutupi oleh siapapun bahwa fenomena modernitas yang belakangan terjadi ternyata berbarengan dengan munculnya fenomena kebangkitan agamaagama dunia yang pada saat yang sama juga tercium aroma konflik antarpemeluk agama. Sebuah keniscayaan bahwa dalam masyarakat yang multi agama seringkali timbul pertentangan antar pemeluk agama yang berbeda. Secara umum konflik antar pemeluk agama tersebut disebabkan oleh beberapa faktor antara lain, seperti pelecehan terhadap agama dan pemimpin spiritual sebuah agama tertentu, perlakuan aparat yang tidak adil terhadap pemeluk agama tertentu, kecemburuan ekonomi dan pertentangan kepentingan politik.

Ketegangan internal dalam umat beragama dan antarumat beragama senantiasa menghiasi perjalanan bangsa ini. Sudah banyak konflik terjadi dalam satu dasawarsa terakhir. Korban tewas dalam konflik sudah tak terhitung. Rumah-rumah peribadatan hancur, sebagian hangus di bakar, 
sebagian luluh lantak dirobohkan, dan sebagian lainnya rusak oleh amuk massa yang terbakar api kemarahan bersentimen keagamaan. Salah satu bagian penting dari konsekuensi tata kehidupan global yang ditandai kemajemukan etnis, budaya, dan agama tersebut, adalah membangun dan menumbuhkan kembali teologi pluralisme dalam masyarakat. Karena pada hakikatnya kita semua adalah sebagai seorang "saudara" dan "sahabat". Bahkan, Islam melalui al-Qur'an dan Hadis juga mengajarkan sikap-sikap toleran. Dalam kaitannya yang langsung dengan prinsip inilah Allah, di dalam al-Qur'an Surat Yunus ([10]: 99), menegur keras Nabi Muhammad Saw ketika beliau menunjukkan keinginan dan kesediaan yang menggebu untuk memaksa manusia menerima dan mengikuti ajaran yang disampaikanya, sebagai berikut:

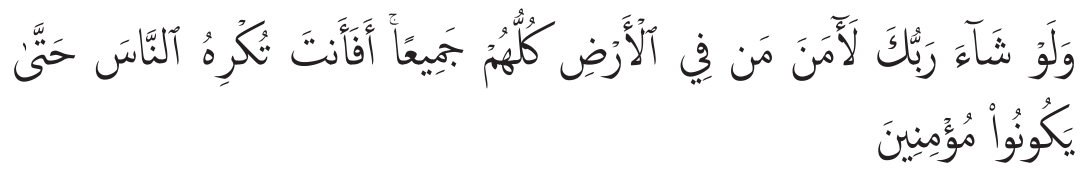

Dan jikalau Tuhanmu menghendaki, tentulah beriman semua orang yang di muka bumi seluruhnya. Maka Apakah kamu (hendak) memaksa manusia supaya mereka menjadi orang-orang yang beriman semuanya.

Ayat di atas telah mengisyaratkan bahwa manusia diberi kebebasan percaya atau tidak. Seperti dicontohkan, kaum Yunus yang tadinya enggan beriman, dengan kasih sayang Allah Swt. memperingatkan dan mengancam mereka. Hingga kemudian kaum Yunus yang tadinya membangkang atas kehendak mereka sendiri, kini atas kehendak mereka sendiri pula mereka sadar dan beriman. Demikianlah prinsip dasar alQur'an yang berkaitan dengan masalah pluralisme dan toleransi. Karena Islam menilai bahwa syarat untuk membuat keharmonisan adalah pengakuan terhadap komponen-komponen yang secara alamiah berbeda. Seperti halnya agama Islam, agama-agama besar lain juga mengajarkan berbagai norma moral untuk mengatur kehidupan bermasyarakat. Agama Hindu mengajarkan norma moral dalam menjalani kehidupan sehari-hari. Agama Kristen menonjolkan aspek spiritualitas dalam mena- 
namkan nilai-nilai moral. Begitu pula agama Islam mengajarkan akhlak terhadap diri sendiri, terhadap orang lain, terhadap flora dan fauna, serta akhlak terhadap Allah dan Rasul-Nya.

Kaitannya dengan aspek pembelajaran ada baiknya perlu diketahui karakteristik khusus mata pelajaran Pendidikan Agama Islam (PAI), salah satunya adalah tidak hanya mengantarkan peserta didik untuk menguasai berbagai ajaran Islam, tetapi yang terpenting adalah bagaimana peserta didik dapat mengamalkan ajaran-ajaran itu dalam kehidupan sehari-hari. Sebagaimana Azyumardi Azra bahwa kedudukan pendidikan agama Islam di berbagai tingkatan dalam sistem pendidikan nasional adalah untuk mewujudkan peserta didik yang beriman dan bertakwa serta berakhlak mulia. Inti dari tujuan pendidikan Islam tersebut adalah untuk membentuk akhlak yang baik, salah satunya adalah manusia yang memiliki sikap toleransi, yaitu manusia yang mampu menghargai dan menghormati sifat dasar, keyakinan, dan perilaku yang dimiliki orang lain. Demi tujuan itu, maka pendidikan dianggap sebagai instrumen penting. Sebab, pendidikan sampai sekarang masih diyakini mempunyai peran besar dalam membentuk karakter individu-individu yang dididiknya. Hal tersebut dengan suatu pertimbangan, bahwa salah satu peran dan fungsi pendidikan agama di antaranya adalah untuk meningkatkan keberagamaan peserta didik dengan keyakinan agama sendiri, dan memberikan kemungkinan keterbukaan untuk menumbuhkan sikap toleransi terhadap agama lain. Dalam konteks ini, tentu saja pengajaran agama Islam yang diajarkan di sekolah-sekolah dituntut untuk selalu menanamkan nilai-nilai toleransi beragama.

Penting kiranya bagi seorang guru atau sekolah untuk menerapkan secara langsung beberapa aksi guna membangun pemahaman keberagamaan yang moderat di sekolah, untuk memperoleh keberhasilan bagi terealisasinya tujuan mulia yaitu perdamaian dan persaudaraan abadi di antara orang-orang yang pada realitasnya memang memiliki agama dan iman berbeda.

\section{Toleransi Beragama dalam Pandangan Islam}


Dalam Kamus Besar Bahasa Indonesia, toleransi berarti bersifat atau bersikap menghargai, membiarkan, membolehkan pendirian (pendapat, pandangan kepercayaan) yang berbeda atau bertentangan dengan pendirian sendiri. Sesesungguhnya toleransi merupakan salah satu diantara sekian ajaran inti dari Islam. Toleransi sejajar dengan ajaran fundamental yang lain, seperti kasih sayang (rahmah) kebijaksanaan (hikmah), kemaslahatan universal (almaslahah al-ammah), dan keadilan. Toleransi merupakan salah satu kebajikan fundamental demokrasi, namun ia memiliki kekuatan ambivalen yang termanifestasi dalam dua bentuk: bentuk solid dan bentuk demokratis. Menjadi toleran adalah membiarkan atau membolehkan orang lain menjadi diri mereka sendiri, menghargai orang lain, dengan menghargai asal-usul dan latar belakang mereka. Toleransi mengundang dialog untuk mengkomunikasikan adanya saling pengakuan. Inilah gambaran toleransi dalam bentuknya yang solid.

Hakikat toleransi pada intinya adalah usaha kebaikan, khususnya pada kemajemukan agama yang memiliki tujuan luhur yaitu tercapainya kerukunan, baik intern agama maupun antaragama. Mengakui eksistensi suatu agama bukanlah berarti mengakui kebenaran ajaran agama tersebut. Kaisar Heraklius dari Bizantium dan al-Mukaukis penguasa Kristen Koptik dari Mesir mengakui kerasulan Nabi Muhammad Saw, namun pengakuan itu tidak lantas menjadikan mereka Muslim. Sampai di sini, sikap dan pandangan teologis Islam terhadap agamaagama yang lain tampak sangat jelas. Seorang ahli tafsir klasik terkemuka mengatakan, "Al-din wahid wa al-syari'ah mukhtalifah" (Din atau agama hanyalah satu, sementara syariat berbeda-beda). Al-Syahrastani teolog Islam dan ahli terkemuka dalam perbandingan agama dalam Husein Muhammad menyampaikan pendapatnya, dalam bukunya al-Milal wa al-Nihal bahwa "al-din adalah ketaatan (al-jaza), dan penghitungan pada hari akhir (alhisab fi yaum al ma'ad). Maka, menurutnya, "al-mutadayyin" (orang yang beragama) adalah orang Islam yang taat, yang mengakui adanya balasan dan perhitungan amal pada hari akhirat. Di sinilah kita harus mengatakan bahwa pluralisme adalah sebuah keniscayaan dan kehendak tuhan yang tidak bisa diingkari. Konsekuensi dari pernyataan ini adalah keniscayaan kita untuk bersikap penuh tasammuh atau toleran terhadap orang 
lain yang berbeda keyakinan atau agama dengan kita, apapun namanya.

Berbagai konflik di masyarakat terjadi, baik secara vertikal maupun horizontal, yang mengakibatkan jatuhnya korban jiwa, harta, dan nilai kemanusiaan. Salah satu ragam konflik yang perlu mendapatkan perhatian ada awal Era Reformasi adalah konflik antarumat beragama. Konflik bernuansa agama di Ambon, Poso, Ketapang, Mataram, dan tempat lain seolah merusak citra Indonesia sebagai negara yang selalu menjunjung kebhinekaaan dan menghargai semuapemeluk agama. Dalam konflikkonflik bernuansa agama tersebut, infrastruktur agama memainkan peran dalam eskalasi konflik. Nilai-nilai agama yang sejalan dengan gagasan konflik dieksplorasi dan dijadkan sebagai pijakan utuk mengabsahkan tindakan kekerasan terhadap umat beragama lain. Oleh karena itu, Islam juga menghendaki pemeluknya untuk menebar toleransi (tasammuh), serta menjauhi sikap buruk sangka terhadap agama lain. Dengan budaya toleransi dan komunikasi diharapakan kekerasan atas nama agama yang sering terjadi belakangan ini. Sehingga tri kerukunan umat beragama (kerukunan internal umat bergama, kerukan antarumat beragama, dan kerukunan antarumat beragama dengan pemerintah) segera terwujud di Indonesia sesuai dengan cita-cita kita bersama. Karena pada hakikatnya toleransi pada intinya adalah usaha kebaikan, khususnya pada kemajemukan agama yang memiliki tujuan luhur yaitu tercapainya kerukunan, baik internal agama maupun antaragama.

Jurhanuddin dalam Amirulloh Syarbini menjelaskan bahwa tujuan kerukunan umat beragama adalah sebagai berikut: Pertama, meningkatkan keimanan dan ketakwaan masing-masing agama. Masing-masing agama dengan adanya kenyataan agama lain, akan semakin mendorong untuk menghayati dan sekaligus memperdalam ajaran-ajaran agamanya, serta semakin berusaha untuk mengamalkan ajaran-ajaran agamanya. Kedua, mewujudkan stabilitas nasioonal yang mantap. Dengan adanya leransi umat beragama secara praktis ketegangan-ketegangan yang ditimbulka akibat perpedaan paham yang berpangkal pada keyakinan keagamaan dapat dihindari apabila kehidupa beragama rukun, dan saling menghormati, maka stabilitas nasional akan terjaga. Ketiga, menjunjung 
dan menyukseskan pembangunan. Usaha pembangunan akan sukses apabila di dukung dan ditopang oleh seganap lapisan masyarakat. Sedangkan jika umat beragama selalu bertikai dan saling menodai, tentu tidak dapa mengarahkan kegiatan untuk mendukung serta membantu pembangunan, bahkan dapat berakibat sebaliknya. Keempat, memelihara dan mempererat rasa persaudaraan. Rasa kebersamaan dan kebangsaan akan akan terpelihara dan terbina dengan baik, bila kepentingan pribadi dan golongan dapat dikurangi.

Pada dasarnya setiap agama membawa kedamaian dan keselarasan hidup. Namun, kenyataannya agama-agama yang tadinya berfungsi sebagai pemersatu tak jarang menjadi suatu unsur konflik. Hal tersebut disebabkan adanya truth claim atau klaim kebenaran pada setiap penganutnya. Padahal jika dipahami lebih mendalam kemajemukan diciptakan untuk membuat mereka saling mengenal, memahami, dan bekerjasama satu sama lain. Ajaran Islam menganjurkan untuk selalu bekerjasama dengan orang lain dan saling tolong menolong dengan sesama manusia. Hal ini menggambarkan bahwa umat Islam diperintahkan untuk menjaga kerukunan umat beragama baik yang seagama maupun yang berbeda agama. Bentuk universalisme Islam digambarkan pada ketidakadaanya paksaan bagi manusia dalam memeluk agama Islam. Hal ini menunjukkan bahwa Islam adalah agama yang menghormati agama lain.

Pluralitas merupakan hukum Ilahi dan Sunnah Ilahiyah yang abadi di semua bidang kehidupan, sehingga pluralitas itu sendiri telah menjadi karakteristik utama makhluk Allah pada level syariat, way of life, dan peradaban, semua bersifat plural. Pluralitas merupakan realitas yang mewujud dan tidak mungkin dipungkiri, yaitu suatu hakikat perbedaan dan keragaman yang timbul semata karena memang adanya kekhususan dan karakteristik yang diciptakan Allah Swt. dalam setiap ciptaan-Nya. Pluralitas yang menyangkut agama yaitu toleransi beragama berarti pengakuan akan eksistensi agama-agama yang berbeda dan beragama dengan seluruh karakteristik dan kekhususannya dan menerima kelainan yang lain beserta haknya untuk berbeda dalam beragama dan berkeyakinan. Konsep dan pemahaman toleransi beragama seperti ini didukung oleh 
dalil naql (teks wahyu), akal dan kenyataan. Allah berfirman dalam Surat al-Baqarah ([2]: 256).

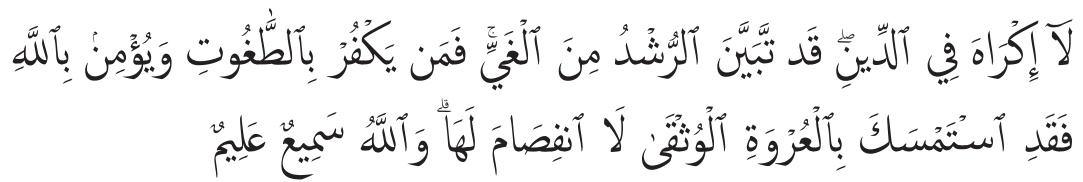

Tidak ada paksaan untuk (memasuki) agama (Islam); Sesungguhnya telah jelas jalan yang benar daripada jalan yang sesat. karena itu Barangsiapa yang ingkar kepada Thaghut dan beriman kepada Allah, Maka Sesungguhnya ia telah berpegang kepada buhul tali yang Amat kuat yang tidak akan putus. dan Allah Maha mendengar lagi Maha mengetahui.

Dalam Surah al-Baqarah ayat 256 patut menjadi perhatian bersama agar dalam dakwah dapat mempertimbangkan aspek toleransi dan kasih sayang yang telah digariskan oleh Allah dan Rasulullah. Tidak diperkenankan adanya pemaksaan, karena Memaksakan kehendak bukanlah hak manusia. Sesungguhnya antara kebaikan dan kezaliman sudah jelas. Kalimat larangan ini diungkapkan dalam bentuk negatif secara mutlak. "Laa ikraaha fid din" tidak ada paksaan untuk "memasuki" agama "Islam". Menurut ahli nahwu ungkapan ini menegasikan semua bentuk pemaksaan, meniadakan pemaksaan secara mendasar. Dalam ayat di atas tidak ada paksaan dalam menganut agama. Mengapa ada paksaan, padahal agama tidak butuh sesuatu, mengapa ada paksaan padahal sekiranya Allah menghendaki, niscaya kamu dijadikan-Nya satu umat saja. (Q.S. al-Maidah [5]: 48). Yang dimaksud dengan tidak ada paksaan dalam menganut agama adalah menganut akidahnya. Ini berarti jika seseorang telah menganut satu akidah maka dia terkait dengan tuntunan-tuntunanya. Dia berkewajiban melaksanakan perintah-perintahnya.

Menuru al-Qaradhawi dalam Anis Malik Thoha menyebutkan empat faktor utama yang menyebabkan toleransi yang unik selalu mendominasi perilaku orang Islam terhadap non-Muslim.

1. Keyakinan terhadap kemuliaan manusia, apapun agamanya, 
kebangsaannya, dan kesukuannya. Kemuliaan mengimplikasikan hak untuk dihormati. Nabi Muhammad tidak pernah membeda-bedakan, sikap toleransi itu direfleksikan dengan cara saling menghormati, saling memuliakan dan saling tolongmenolong. Jadi sudah jelas, bahwa sisi akidah atau teologi bukanlah urusan manusia, melainkan Tuhan Swt. dan tidak ada kompromi serta sikap toleran di dalamnya. Sedangkan kita bermu’amalah dari sisi kemanusiaan kita.

2. Keyakinan bahwa perbedaan manusia dalam agama dan keyakinan merupakan realitas yang dikehendaki Allah Swt. yang telah memberi mereka kebebasan untuk memilih iman atau kufur. Kehendak Allah pasti terjadi, dan tentu menyimpan hikmah yang luar biasa. Oleh karenanya, tidak dibenarkan memaksa untuk Islam. Allah berfirman dalam Surat Yunus ([10]: 99):

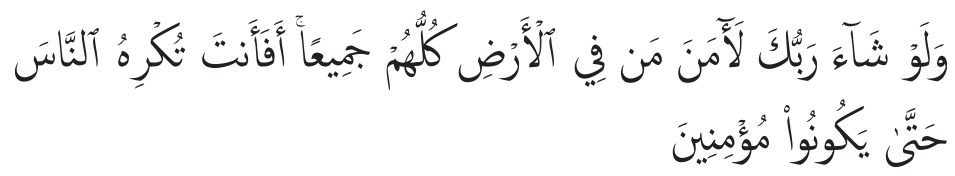

Dan jikalau Tuhanmu menghendaki, tentulah beriman semua orang yang di muka bumi seluruhnya. Maka Apakah kamu (hendak) memaksa manusia supaya mereka menjadi orang-orang yang beriman semuanya.

Ayat dia tas telah mengisyaratkan bahwa manusia diberi kebebasan percaya atau tidak. Seperti dicontohkan, kaum Yunus yang tadinya enggan beriman, dengan kasih sayang Allah Swt. memperingatkan dan mengancam mereka. Hingga kemudian kaum Yunus yang tadinya membangkang atas kehendak mereka sendiri, lalu atas kehendak mereka sendiri pula mereka sadar dan beriman.

3. Seorang Muslim tidak dituntut untuk mengadili kekafiran orang kafir, atau menghukum kesesatan orang sesat. Allah-lah yang akan mengadili mereka di hari perhitungan nanti. Dengan demikian hati seorang Muslim menjadi tenang, tidak perlu ter- 
jadi konflik batin antara kewajiban berbuat baik dan adil kepada mereka, dan dalam waktu yang sama, harus berpegang teguh pada kebenaran keyakinan sendiri. Allah Swt. berfirman dalam Surat al-Kahfi ([18]: 29), yaitu:

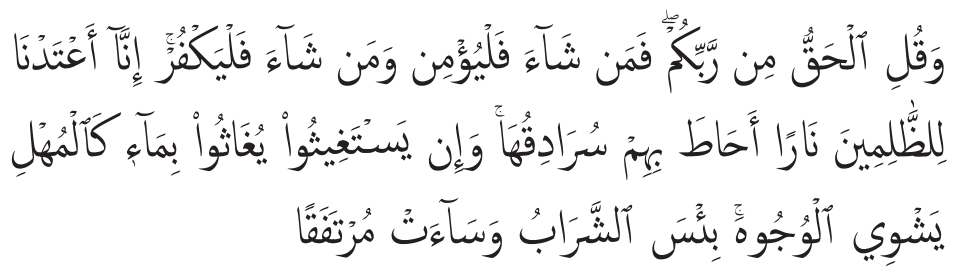

Dan Katakanlah: "Kebenaran itu datangnya dari Tuhanmu; Maka Barangsiapa yang ingin (beriman) hendaklah ia beriman, dan Barangsiapa yang ingin (kafir) Biarlah ia kafir". Sesungguhnya Kami telah sediakan bagi orang-orang zalim itu neraka, yang gejolaknya mengepung mereka. dan jika mereka meminta minum, niscaya mereka akan diberi minum dengan air seperti besi yang mendidih yang menghanguskan muka. Itulah minuman yang paling buruk dan tempat istirahat yang paling jelek.

Ayat ini diturunkan untuk memerintahkan Rasul Saw. yang menegaskan kepada semua kaum, termasuk kaum musyrikin,

Dan katakanlah wahai Nabi Muhammad bahwa: "kebenaran, yakni wahyu Ilahi yang aku sampaikan ini datangnya dari Tuhan pemelihara kamu dalam segala hal; maka barang siapa diantara kamu, atau selain kamu yang ingin beriman tentang apa yang kusampaikan ini maka hendaklah ia beriman, keuntungan dan manfaatnya akan kembali pada dirinya sendiri, dan barang siapa di antara kamu atau selain kamu yang ingin kafir dan menolak pesan-pesan Allah, maka biarlah ia kafir, walau sekaya dan setinggi apapun kedudukan sosialnya. Tidaklah aku apalagi Allah Swt. akan mengalami sedikit kerugian pun dengan kekafirannya, sebaliknya, dialah sendiri yang akan merugi dan celaka dengan perbuatannya yang telah menganiaya dirinya sendiri. 
4. Keyakinan bahwa Allah Swt. memerintahkan untuk berbuat adil dan mengajak kepada budi pekerti mulia meskipun kepada orang musyrik. Begitu juga Allah Swt. mencela perbuatan zalim meskipun terhadap orang kafir. Seperti firman Allah Swt. dalam Surat al-Maidah ([5]: 8).

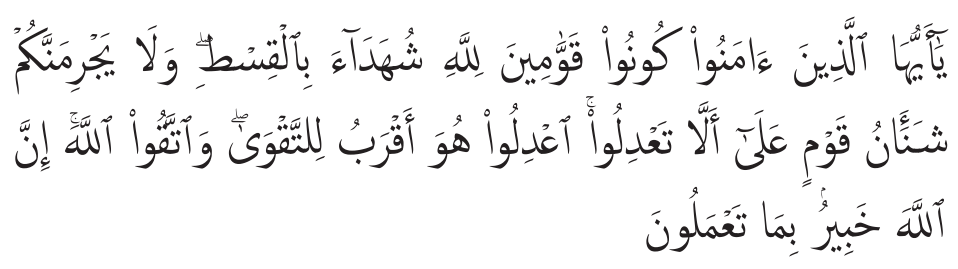

Hai orang-orang yang beriman hendaklah kamu Jadi orang-orang yang selalu menegakkan (kebenaran) karena Allah, menjadi saksi dengan adil. dan janganlah sekali-kali kebencianmu terhadap sesuatu kaum, mendorong kamu untuk Berlaku tidak adil. Berlaku adillah, karena adil itu lebih dekat kepada takwa. dan bertakwalah kepada Allah, Sesungguhnya Allah Maha mengetahui apa yang kamu kerjakan.

Dalam ayat tersebut Allah melarang ummatnya menebar permusuhan dan kebencian terhadap suatu kaum yang yang dapat mendorong terhadap sikap tidak adil terhadap kaum tersebut. Jadi terhadap mereka pun kita harus tetap memberi kesaksian sesuatu dengan hak yang patut mereka terima apabila mereka patut menerimanya. Karena orang mukmin mesti mengutamakan keadilan dari pada berlaku aniaya dan berat sebelah keadilan harus ditempatkan di atas hawa nafsu dan kepentingankepentingan pribadi, dan di atas rasa cinta dan permusuhan, apapun sebabnya.

Beberapa ayat al-Qur'an di atas menerangkan ungkapan yang sangat tegas dan gamblang mengenai pandangan Islam terhadap kebebasan beragama dan berkeyakinan, yang merupakan ciri kebebasan manusia yang paling utama. Bahkan, menurut Sayyid Quthb, kebebasan ini meru- 
pakan hak asasi manusia yang nomor satu yang tanpanya manusia bukan lagi manusia. Hal ini juga telah dicontohkan oleh Nabi Muhammad Saw. Di tengah masyarakat yang heterogen, yang diwarnai keteganganketegangan konflik, nabi melakukan gerakan besar yang berpengaruh bagi kesatuan ummah. Pertama, hijrah, implikasi sosialnya terletak pada persaudaraan antara Muhajirin dan Anshar. Bukan persaudaraan biasa, kaum Anshar melapangkan kekayaanya untuk dapat dinikmati pula oleh kaum Muhajirin. Kedua, piagam Madinah, ketegangan antara Yahudi dan Muslim, baik Anshar maupun Muhajirin, begitu pula antarkelompok lain dan juga kemajemukan komunitas Madinah membuat Nabi melakukan negosiasi dan konsolidasi melalui perjanjian tertulis yang kemudian familiar disebut Piagam Madinah konstitusi ditanda tangani oleh seluruh komponen yang ada di Madinah yang meliputi Nasrani, Yahudi, Muslim dan Musyrikin. Dalam 47 pasal yang termuat di dalamnya statemen yang diangkat meliputi masalah monotheisme, persatuan kesatuan, persamaan hak, keadilan kebebasan beragama, bela negara, pelestarian adat perdamaian dan proteksi. Konstitusi tersebut memberi tauladan kita tentang pembentukan ummah, menghargai hak asasi manusia dan agama lain, persatuan segenap warga negara, dan yang terpenting adalah tanggung jawab menciptakan kedamaian.

Dengan demikian tampak bahwa nilai-nilai ajaran Islam menjadi dasar bagi hubungan antarumat manusia secara universal, dengan tidak mengenal suku, adat, budaya, dan agama. Akan tetapi, yang dilarang Islam hanya pada konsep akidah dan ibadah. Kedua konsep tersebut yang tidak bisa dicampuri oleh umat non Islam. Namun aspek sosial kemasyarakatan dapat bersatu dan kerjasama yang baik. Perlu ditambahkan bahwa mengakui eksistensi praktis agama-agama lain yang beragam dan saling berseberangan ini, dalam pandangan Islam tidak secara otomatis mengakui legalitas dan kebenarannya. Melainkan menerima kehendak ontologis Allah Swt. dalam menciptakan agama-agama berbeda-beda dan beragam. Mengakui realitas perbedaan dan hak seorang untuk berbeda sama sekali tidak berarti syariat dakwah mesti digugurkan. Bahkan sebaliknya, justru malah semakin menegaskan urgensi dan pentingnya dakwah. Sebab di satu pihak, hakikat perbedaan 
itu sendiri sejatinya memungkinkan masing-masing faksi yang saling berbeda untuk melihat dirinya sebagai entitas yang memiliki kelebihan, nilai dan kebenaran, dan untuk melaksanakan hak-haknya, serta untuk mengekspresikan jati dirinya secara bebas sebagai upaya mewujudkan kelebihan, nilai, dan kebenaran yang dimilikinya.

\section{Toleransi Bergama di Sekolah}

Kemanusiaan adalah nilai-nilai objektif yang dibatasi oleh kultur tertentu, nilai kebebasan, kemerdekaan, dan kebahagiaan. Persamaan hak adalah nilai-nilai kemanusiaan yang dibangun di atas fondasi demokrasi. Antara pendidikan demokratis dan pendidikan pluralis-multikultural merupakan sebuah rangkaian. Masing-masing saling bergantung dan saling mempengaruhi. Oleh karena itu, membangun pendidikan yang berparadigma pluralis-multikultural merupakan kebutuhan yang tidak bisa ditunda lagi. Dengan paradigma semacam ini, pendidikan diharapkan akan melahirkan anak didik yang memiliki cakrawala pandang yang luas, menghargai perbedaan, penuh toleransi, dan penghargaan terhadap segala bentuk perbedaan.

Sikap pluralis dan toleran semacam inilah yang seharusnya ditumbuh-kembangkan lewat berbagai macam institusi yang ada termasuk lewat jalur pendidikan. Berpedoman pada standar kompetensi lulusan dan standar isi serta panduan penyusunan kurikulum yang dikembangkan oleh Badan Standar Nasional Pendidikan (BSNP) yang dibentuk berdasarkan Peraturan Pemerintah Nomor 19 Tahun 2005. Kurikulum dikembangkan salah satunya dengan memperhatikan keragaman karakteristik peserta didik, kondisi daerah, dan jenjang serta jenis pendidikan, tanpa membedakan agama, suku, budaya dan adat istiadat, serta status sosial ekonomi dan gender. Kurikulum tersebut dilaksanakan dengan menegakkan kelima pilar belajar, yaitu (a) belajar untuk beriman dan bertakwa kepada Tuhan Yang Maha Esa, (b) belajar untuk memahami dan menghayati, (c) belajar untuk mampu melaksanakan dan berbuat secara efektif, (d) belajar untuk hidup bersama dan berguna bagi orang lain, dan (e) belajar untuk membangun dan menemukan jati diri, melalui 
proses pembelajaran yang aktif, kreatif, efektif, dan menyenangkan.

Adapun berdasarkan Peraturan Menteri Pendidikan Nasional Nomor 23 Tahun 2006 Tanggal 23 Mei 2006 tentang Standar Kompetensi Lulusan, di dalamnya menyebutkan bahwa standar kompetensi lulusan satuan pendidikan pada semua jenjang pendidikan peserta didik mampu menghargai keberagaman agama, budaya, suku, ras, dan golongan sosial ekonomi di lingkungan sekitarnya. Sehubungan dengan hal tersebut, peran sekolah sebagai lembaga pendidikan formal sangat penting dalam membangun lingkungan pendidikan yang pluralis dan toleran terhadap semua pemeluk agama. Untuk membentuk pendidikan yang menghasilkan manusia yang memiliki kesadaran pluralis dan toleran diperlukan rekonstruksi pendidikan sosial keagamaan dalam pendidikan agama. Salah satunya dengan mengupayakan untuk menanamkan nilainilai toleransi pada peserta didik sejak dini yang berkelanjutan dengan mengembangkan rasa saling pengertian dan memiliki terhadap umat agama lain.

Dalam implementasinya di sekolah, sekolah sebaiknya memperhatikan langkah-langkah sebagai berikut: pertama, sekolah sebaiknya membuat dan menerapkan undang-undang lokal, yaitu undang-undang sekolah yang diterapkan secara khusus di satu sekolah tertentu. Dalam undang-undang tersebut, tentunya salah satu poin penting yang tercantum adalah adanya larangan terhadap segala bentuk diskriminasi agama di sekolah tersebut. Dengan diterapkannya undang-undang ini diharapkan semua unsur yang ada seperti guru, kepala sekolah, pegawai, administrasi, dan murid dapat belajar untuk selalu menghargai orang lain yang berbeda agama di lingkungan mereka. Kedua, untuk membangun rasa pengertian sejak dini antarsiswa yang mempunyai keyakinan keagamaan yang berbeda maka sekolah harus berperan aktif menggalakkan dialog keagamaan atau dialog antariman yang tentunya tetap berada dalam bimbingan guru-guru dalam sekolah tersebut. Dialog antariman semacam ini merupakan salah satu upaya yang efektif agar siswa dapat membiasakan diri melakukan dialog dengan penganut agama yang berbeda. Ketiga, hal lain yang penting dalam penerapan pendidikan 
toleransi yaitu kurikulum, dan buku-buku pelajaran yang dipakai, dan diterapkan di sekolah. Kurikulum pendidikan yang multikultural merupakan persyaratan utama yang tidak bisa ditolak dalam menerapkan strategi pendidikan ini. Pada intinya, kurikulum pendidikan multikultural adalah kurikulum yang memuat nilai-nilai pluralisme dan toleransi keberagamaan. Begitu pula buku-buku, terutama buku-buku agama yang di pakai di sekolah, sebaiknya adalah buku-buku yang dapat membangun wacana peserta didik tentang pemahaman keberagamaan yang inklusif dan moderat.

\section{Peran Guru dalam Pendidikan Toleransi di Sekolah}

Pandangan Islam pada pembahasan sebelumnya relevan dengan UUD 1945 Pasal 29 ayat 2 yang berbunyi, "Negara menjamin kemerdekaan tiap-tiap penduduk untuk memeluk agamanya masing-masing dan untuk beribadah menurut kepercayaan agamanya itu." Keberadaan bangsa Indonesia sebagai negara yang plural merupakan berkah dan kekayaan yang patut disyukuri. Namun, di sisi lain, perlu disadari bahwa aspek pluralitas tersebut menjadikan bangsa ini menjadi rentan terhadap ancaman konflik.

Sehubungan dengan hal tersebut, pendidikan Islam di Indonesia memiliki peranan penting dalam memberi kontribusi bagi persatuan bangsa di masa depan. Dalam hal ini konsep pendidikan Islam yang peduli pada pluralisme akan bermakna positif bila tergambar luas pada realitas aktual kehidupan bangsa Indonesia yang pluralistik. Sebagai umat dengan jumlah terbesar di Indonesia, maka peran umat Islam sangat signifikan dalam menentukan masa depan bangsa ini. Umat islam semestinya memberikan suri tauladan dalam sikap dan tindakan atas dasar prinsip toleransi sebagaimana diajarkan ajaran Islam, dan sebagai mana juga yang telah terabaikan dalam sejarah sosial historis umat Islam terutama pada periode Rasulullah Saw.

Pendidikan dianggap sebagai instrumen penting sebab "pendidikan" sampai sekarang masih diyakini mempunyai peran besar dalam mem- 
bentuk karakter individu-individu yang dididiknya. Hal tersebut dengan suatu pertimbangan, bahwa salah satu peran dan fungsi pendidikan agama diantaranya adalah untuk meningkatkan keberagamaan peserta didik dengan keyakinan agama sendiri, dan memberikan kemungkinan keterbukaan untuk menumbuhkan sikap toleransi terhadap agama lain. Dalam konteks ini, tentu saja pengajaran agama Islam yang diajarkan di sekolah-sekolah di tuntut untuk selalu menanamkan nilai-nilai toleransi beragama.

Inilah agenda dan program baru yang harus masuk dalam kalkulasi umat beragama, khususnya bagi para pendidik. Karena pendidik merupakan faktor penting dalam mengimplementasikan nilai-nilai toleransi keberagamaan yang moderat dalam proses pembelajaran di sekolah. Pendidik mempunyai posisi penting dalam pendidikan multikultural karena dia merupakan satu target dari strategi pendidikan ini. Apabila seorang guru memiliki paradigma pemahaman keberagamaan yang moderat maka dia juga akan mampu untuk mengajarkan dan mengimplementasikan nilai-nilai keberagamaan tersebut terhadap siswa di sekolah.

Peran guru dalam hal ini meliputi: pertama, seorang guru harus mampu bersikap demokratis dalam segala tingkah lakunya, baik sikap maupun perkataannya, tidak diskriminatif terhadap murid-murid yang menganut agama yang berbeda dengannya. Sebagai salah satu contoh ketika seorang guru sejarah menerangkan tentang Perang Salib (10991291) yang melibatkan kelompok Islam dan Kristen maka dia harus mampu untuk bersikap tidak memihak terhadap salah satu kelompok yang terlibat dalam perang tersebut. Meskipun agama yang dianutnya sama dengan salah satu yang terlibat dalam perang tersebut.

Kedua, guru seharusnya memiliki kepedulian yang sangat tinggi terhadap kejadian-kejadian tertentu yang berhubungan dengan agama. Contohnya, ketika terjadi pemboman yang dilakukan oleh para teroris maka guru yang memiliki wawasan multikultural harus mampu menjelaskan keprihatinannya terhadap peristiwa tersebut. Kemudian sebaiknya seorang guru mampu menjelaskan bahwa kejadian tersebut seharusnya jangan sampai terjadi. Karena di dalam semua agama baik 
Islam, Katolik, Budha, Hindu, Yahudi, Konghucu, dan kepercayaan lainnya jelas dikatakan bahwa segala macam bentuk kekerasan dalam memecahkan masalah adalah dilarang. Dialog dan musyawarah adalah cara-cara penyelesaian segala bentuk masalah yang sangat dianjurkan oleh semua agama dan kepercayaan yang ada.

Dari beberapa penjelasan di atas dapat disimpulkan bahwa pendidik merupakan faktor penting dalam mengimplementasikan nilai-nilai toleransi keberagamaan yang moderat dalam proses pembelajaran di sekolah. Pendidik mempunyai posisi penting dalam pendidikan multi kultural karena dia merupakan satu target dari strategi pendidikan ini. Apabila seorang guru memiliki paradigma pemahaman keberagamaan yang moderat maka dia juga akan mampu untuk mengajarkan dan mengimplementasikan nilai-nilai keberagamaan tersebut terhadap siswa di sekolah.

\section{Model Penanaman Nilai-Nilai Toleransi pada Pembelajaran PAI di Sekolah}

\section{Penanaman Nilai-Nilai Toleransi Beragama pada Pembelajaran PAI di Sekolah}

Konsepsi pendidikan Islam yang berdasarkan al-Qur'an dan Hadis memiliki jangkauan ke depan. Karena itu falsafah pendidikan Islam lebih tepat jika menggunakan falsafah progresivisme, yang artinya bahwa pendidikan Islam harus mampu mendahului gerak perubahan sosial. Posisi pendidikan Islam dimasa yang akan datang dalam kaitannya dengan perubahan sosio kultural ini adalah untuk memberikan makna pengembangan nilai-nilai kemanusiaan yang lebih adil dan beradab. Pendidikan Islam merupakan pengembangan potensi, pewarisan budaya, dimana teknologi dan sains ada di dalamnya, dan interaksi antara potensi manusia dengan budaya. Konsekwensi logis dari pendidikan Islam semacam ini adalah pendidikan Islam harus mampu menciptakan insan-insan Muslim yang memiliki kreativitas tinggi dan siap berkiprah di dunia modern. Dalam kaitannya dengan modernisasi pendidikan Islam maka penting 
untuk tetap berpegang pada causa finalis untuk menjadikan proyeksi ke masa depan, untuk mengantisipasi kiprah pendidikan Islam. Modernisasi pendidikan Islam berorientasi pada lima hal, yaitu pertama, pendidikan Islam harus menuju pada integrasi ilmu antara ilmu agama dan ilmu umum, untuk tidak melahirkan dikotomi ilmu pengetahuan yang melahirkan jurang pemisah antara ilmu agama dan bukan agama. Kedua, pendidikan Islam menuju terciptanya sikap dan perilaku toleran, lapang dada dalam berbagai hal dan bidang, terutama toleran dalam perbedaan pendapat penafsiran ajaran Islam. Ketiga, pendidikan Islam menuju pada intensifikasi pemahaman bahasa asing sebagai alat untuk menguasai dan mengembangkan ilmu pengetahuan yang semakin pesat perkembangannya. Keempat, pendidikan yang menumbuhkan kemampuan untuk berswadaya dan mandiri dalam kehidupan. Kelima, pendidikan yang menumbuhkan etos kerja, mempunyai apresiasi terhadap kerja, disiplin, dan jujur.

Namun demikian, orientasi pendidikan agama Islam selama ini dinilai masih memiliki beberapa kelemahan. Sekadar contoh, pada era reformasi dan globalisasi budaya seperti saat ini, tidak terlalu penting menekankan "kebanggaan diri sendiri secara terselubung" dengan disertai sikap merendahkan orang lain. Tidak terlalu esensial untuk mengulang-ulang pernyataan bahwa "umat Islam adalah tinggi dan tidak ada yang menandinginya", yang berakibat secara tidak sengaja pada pembentukan sikap eksklusif dan menonjolkan truth claim. Dalam era modernitas uraian sedemikian dirasa kurang demokratis dan tidak mendidik. Uraian-uraian yang berbau seperti itu perlu diganti dengan yang lebih demokratis dan menonjolkan pentingnya prestasi, mengingat daya kritis masyarakat luas sudah semakin mengikat. Orientasi semacam ini menyebabkan terjadinya keterpisahan dan kesenjangan antarajaran Islam dan realitas perilaku pemeluk agamanya. Oleh karena itu, modernisasi pendidikan Islam harus berorientasi pada aspek pengetahuan dan teknologi (scientific paradigm) dan aspek kemanusiaan di atas segala perbedaan baik dalam hal budaya maupun dalam keberagamaan.

Salah satu komponen dalam pendidikan adalah pembelajaran. 
Untuk memperbaiki realitas masyarakat, perlu dimulai dari proses pembelajaran. Berkaitan dengan hal tersebut maka pendidikan agama Islam di sekolah-sekolah swasta maupun umum diharapkan mampu menanamkan nilai-nilai toleransi pada proses pembelajaran di sekolah, yaitu dengan menggunakan pembelajaran yang mengarah pada upaya menghargai perbedaan di antara sesama manusia sehingga terwujud ketenangan dan ketenteraman tatanan kehidupan masyarakat. Konsep pendidikan yang pluralis-toleran tidak hanya dibutuhkan oleh seluruh anak atau peserta didik, tidak hanya menjadi target prasangka sosial kultural, atau anak yang hidup dalam lingkungan sosial yang heterogen, namun ke seluruh anak didik sekaligus guru dan orang tua perlu terlibat dalam pendidikan pluralis-toleran. Dengan demikian, anak didik dapat dipersiapkan secara aktif sebagai warga Negara yang secara etnik, kultural, dan agama beragam, menjadi manusia-manusia yang menghargai perbedaan, bangga terhadap diri sendiri, lingkungan dan realitas yang majemuk.

Dalam kaitannya dengan proses pembelajaran agama, hal penting yang harus dipahami adalah karakteristik pluralis.

a. Belajar dalam Perbedaan. Pendidikan yang menopang proses dan produk pendidikan nasional hanya bersandar pada tiga pilar utama yang menopang proses dan produk pendidikan nasional, yaitu how to know, how to do, dan how to be. Pada pilar ketiga how to be menekankan pada cara "menjadi orang" sesuai dengan karakteristik dan kerangka pikir anak didik. Dalam konteks ini, how to life and work together with others pada kenyataannya belum secara mendasar mengajarkan sekaligus menanamkan ketrampilan hidup bersama dalam komunitas yang plural secara agama, kultural, ataupun etnik. Selanjutnya pilar keempat sebagai suatu jalinan komplementer terhadap tiga pilar lainnya dalam praktik pendidikan meliputi proses pengembangan sikap toleran, empati, dan simpati, yang merupakan prasyarat esensial bagi keberhasilan dan proeksistensi dalam keragaman agama. Toleransi adalah kesiapan dan kemampuan batin bersama orang lain 
yang berbeda secara hakiki, meskipun terhadap konflik dengan pemahaman kita. Pendidikan agama dengan menekankan nilainilai toleransi dirancang, didesain untuk menanamkan: 1) sikap toleransi dari tahap yang minimalis, dari yang sekadar dekoratif hingga yang solid; 2) klasifikasi nilai-nilai kehidupan bersama menurut perspektif agama-agama; 3) pendewasaan emosional; 4) kesetaraan dan partisipasi; dan 5) kontrak sosial baru dan aturan main kehidupan bersama antaragama.

b. Membangun Saling Percaya. Rasa saling percaya adalah salah satu modal sosial terpenting dalam penguatan masyarakat.

c. Memelihara Saling Pengertian. Memahami bukan serta menyetujui. Saling memahami adalah kesadaran bahwa nilai-nilai mereka dan kita adalah berbeda, dan mungkin saling melengkapi serta memberi kontribusi terhadap relasi yang dinamis dan hidup. Agama mempunyai tanggung jawab membangun landasan etnis untuk bisa saling memahami diantara entitas-entitas agama dan budaya yang plural-multikultural.

d. Menjunjung Tinggi Sikap Saling Menghargai. Dengan desain pembelajaran semacam ini, diharapkan akan tercipta sebuah proses pembelajaran yang mampu menumbuhkan kesadaran pluralis di kalangan anak didik. Jika desain semacam ini dapat terimplementasi dengan baik, harapan terciptanya kehidupan yang damai, penuh toleransi, dan tanpa konflik lebih cepat akan lebih terwujud. Sebab pendidikan merupakan media dengan kerangka yang paling sistematis, paling luas penyebarannya, dan paling efektif kerangka implementasinya.

\section{Model Penanaman Nilai-nilai Toleransi Beragama pada Pemb- elajaran PAI di Sekolah}

Karakteristik khusus mata pelajaran PAI, salah satunya adalah tidak hanya mengantarkan peserta didik untuk menguasai berbagai ajaran Islam, tetapi yang terpenting adalah bagaimana peserta didik 
dapat mengamalkan ajaran-ajaran itu dalam kehidupan sehari-hari, sebagaimana pendapat Azyumardi Azra bahwa kedudukan pendidikan agama Islam di berbagai tingkatan dalam sistem pendidikan nasional adalah untuk mewujudkan peserta didik yang beriman dan bertakwa serta berakhlak mulia.

Inti dari tujuan pendidikan Islam tersebut adalah untuk membentuk akhlak yang baik salah satunya adalah manusia yang memiliki sikap toleransi dalam bersosialisasi. Untuk merealisasi tujuan dan fungsi pendidikan yang dapat menumbuhkan sikap toleransi beragama pada peserta didik, pendidikan di sekolah harus menekankan penanaman nilai-nilai toleransi beragama dalam pembelajaran PAI. Metode yang dipilih oleh pendidik dalam pembelajaran tidak boleh bertentangan dalam pembelajaran. Metode harus mendukung kemana kegiatan interaksi edukatif berproses guna mencapai tujuan. Tujuan pokok pembelajaran adalah mengembangkan kemampuan anak secara individu agar bisa menyelesaikan segala permasalahan yang dihadapinya. Proses pembelajaran yang baik hendaknya menggunakan metode secara bergantian atau saling bahu membahu satu sama lain sesuai dengan situasi dan kondisi. Tugas guru adalah memilih diantara ragam metode yang tepat untuk menciptakan suatu iklim pembelajaran yang kondusif.

Ada beberapa model pengajaran yang dapat diterapkan dalam penanaman nilai-nilai toleransi beragama di sekolah.

\section{a. Model Pengajaran Komunikatii}

Dengan dialog memungkinkan setiap komunitas yang notabenenya memiliki latar belakang agama yang berbeda dapat mengemukakan pendapatnya secara argumentatif. Dalam proses inilah diharapkan nantinya memungkinkan adanya sikap saling mengenal antar tradisi dari setiap agama yang dipeluk oleh masing-masing peserta didik sehingga bentukbentuk truth claim dapat diminimalkan, bahkan mungkin dapat dibuang jauh-jauh.

Metode dialog ini pada akhirnya akan dapat memuaskan semua 
pihak, sebab metodenya telah mensyaratkan setiap pemeluk agama untuk bersikap terbuka. Di samping juga untuk bersikap objektif dan subjektif sekaligus. Objektif berarti sadar membicarakan banyak iman secara fair tanpa harus mempertanyakan mengenai benar salahnya suatu agama. Subjektif berarti pengajaran seperti itu sifatnya hanya untuk mengantarkan setiap anak didik memahami dan merasakan sejauh mana keimanan tentang suatu agama dapat dirasakan oleh setiap orang yang mempercayainya.

\section{b. Model Pengajaran Aktii}

Selain dalam bentuk dialog, pelibatan siswa dalam pembelajaran dilakukan dalam bentuk "belajar aktif". Dengan menggunakan model pengajaran aktif memberi kesempatan pada siswa untuk aktif mencari, menemukan, dan mengevaluasi pandangan keagamaannya sendiri dengan membandingkannya dengan pandangan keagamaan siswa lainnya, atau agama-agama di luar dirinya. Dalam hal ini, proses mengajar lebih menekankan pada bagaimana mengajarkan agama dan bagaimana mengajarkan tentang agama. 53

Kedua model pengajaran di atas, menitik beratkan pada upaya guru untuk membawa siswa agar mengalami langsung interaksi dalam keragaman. Untuk kepentingan pendidikan agama dalam menanamkan nilai-nilai toleransi, proses pembelajaran dapat dilaksanakan melalui pembuatan kelompok belajar yang di dalamnya terdiri dari siswa-siswa yang memiliki latar belakang agama dan kepercayaan yang berbeda. Modifikasi kelompok belajar ini bisa juga dilakukan dengan mengakomodir sekaligus keragaman etnik, gender, dan kebudayaan. Jadi, dimungkinkan setiap kelompok terdiri dari siswa lelaki dan perempuan dengan agama dan kepercayaan yang berbeda.

Ada beberapa keterampilan hidup bersama yang sedang dilatihkan dalam proses pembelajaran seperti ini antara lain: dialog kelompok akan membawa siswa berani mengekspresikan pendapatnya meski harus berbeda dengan yang lain. Mereka juga belajar mendengar pendapat orang 
lain dari yang pro maupun kontra. Siswa dilatih untuk mensintesiskan pandangan-pandangan yang beragam terhadap tema yang dibahas. Tugas guru dalam proses ini sebagai fasilitator, mengarahkan dialog dan memberi penguatan bila dirasa perlu.

Pada model belajar semacam ini, tugas guru adalah harus mampu menjelaskan tugas tersebut, kemana mereka harus mencari informasi, bagaimana mengolah informasi tersebut, kemana mereka harus mencari informasi tersebut dan membahasnya dalam kelas, sampai mereka memiliki kesimpulan yang sudah dibahas dalam kelompoknya masingmasing. Dalam proses pembahasan inilah, guru terus memberikan bimbingan dan arahan.

Dalam proses pembelajaran dengan menggunakan model pembelajaran aktif dan komunikatif hal penting yang perlu diperhatikan adalah media pembelajaran yang digunakan. Media pembelajaran Pendidikan Agama Islam adalah sesuatu yang dapat dijadikan sarana dan prasarana yang dipergunakan untuk membantu tercapainya tujuan pembelajaran PAI. Dalam praktik di lapangan seringkali kita temukan istilah lain yang serupa atau mungkin berkonotasi yang sama yaitu "alat peraga" dan "alat bantu belajar". Dari ketiga pengertian para ahli bersikap dengan membedakannya, namun adapula yang menggunakannya dengan interpretasi yang sama.

Dalam proses pembelajaran Pendidikan Agama Islam, dengan menggunakan media diharapkan siswa yang belajar tidak hanya sekedar meniru, mencontoh, atau melakukan, apa yang diberikan kepadanya tetapi ia juga secara aktif berupaya untuk berbuat atas dasar keyakinannya. Bentuk pendidikan semacam inilah yang akan dapat dijadikan sebagai model pendidikan yang berupaya menumbuh kembangkan perasaan cinta kasih dan saling menghormati diantara manusia yang pada dasarnya memiliki perbedaan-perbedaan agama, etnis, ras, dan agama. Sehingga tentunya model pendidikan seperti ini akan dapat meminimalisir konflik dan menuju persatuan sejati. 


\section{Penutup}

Menjadi toleran adalah membiarkan atau membolehkan orang lain menjadi diri mereka sendiri, menghargai orang lain, dengan menghargai asal-usul dan latar belakang mereka. Toleransi mengundang dialog untuk mengkomunikasikan adanya saling pengakuan. Inilah gambaran toleransi dalam bentuknya yang solid. Dalam implementasinya di sekolah, nilai-nilai toleransi perlu ditanamkan dengan memperhatikan langkah-langkah sebagai berikut: pertama, sekolah sebaiknya membuat dan menerapkan undang-undang lokal, yaitu undang-undang sekolah yang diterapkan secara khusus di satu sekolah tertentu. Kedua, untuk membangun rasa pengertian sejak dini antarsiswa yang mempunyai keyakinan keagamaan yang berbeda, maka sekolah harus berperan aktif menggalakkan dialog keagamaan atau dialog antariman yang tentunya tetap berada dalam bimbingan guru-guru dalam sekolah tersebut. Ketiga, hal lain yang penting dalam penerapan pendidikan toleransi yaitu kurikulum, dan buku-buku pelajaran yang dipakai, dan diterapkan di sekolah. Kurikulum pendidikan yang multikultural merupakan persyaratan utama yang tidak bisa ditolak dalam menerapkan strategi pendidikan ini. Pada intinya, kurikulum pendidikan multikultural adalah kurikulum yang memuat nilai-nilai pluralisme dan toleransi keberagamaan. Begitu pula buku-buku, terutama buku-buku agama yang di pakai di sekolah, sebaiknya adalah buku-buku yang dapat membangun wacana peserta didik tentang pemahaman keberagamaan yang inklusif dan moderat. Pendidikan dianggap sebagai instrumen penting sebab pendidikan sampai sekarang masih diyakini mempunyai peran besar dalam membentuk karakter individu-individu yang dididiknya. Hal tersebut dengan suatu pertimbangan, bahwa salah satu peran dan fungsi pendidikan agama diantaranya adalah untuk meningkatkan keberagamaan peserta didik dengan keyakinan agama sendiri, dan memberikan kemungkinan keterbukaan untuk menumbuhkan sikap toleransi terhadap agama lain. Dalam konteks ini, tentu saja pengajaran agama Islam yang diajarkan di sekolah-sekolah dituntut untuk selalu menanamkan nilai-nilai toleransi beragama. Beberapa model pengajaran yang dapat dapat menjadi pilihan 
untuk penanaman nilai-nilai toleransi beragama di sekolah di antaranya:

Pertama, model pengajaran komunikatif. Metode dialog ini pada akhirnya akan dapat memuaskan semua pihak, sebab metodenya telah mensyaratkan setiap pemeluk agama untuk bersikap terbuka. Di samping juga untuk bersikap objektif dan subjektif sekaligus. Objektif berarti sadar membicarakan banyak iman secara fair tanpa harus mempertanyakan mengenai benar salahnya suatu agama. Subjektif berarti pengajaran bersifat hanya untuk mengantarkan setiap anak didik memahami dan merasakan sejauhmana keimanan tentang suatu agama dapat dirasakan oleh setiap orang yang mempercayainya. Kedua, model pengajaran aktif. Selain dalam bentuk dialog, pelibatan siswa dalam pembelajaran dilakukan dalam bentuk "belajar aktif”. Dengan menggunakan model pengajaran aktif, akan dapat memberi kesempatan pada siswa untuk aktif mencari, menemukan, dan mengevaluasi pandangan keagamaannya sendiri dengan membandingkannya dengan pandangan keagamaan siswa lainnya, atau agama-agama di luar dirinya. Dalam hal ini, proses mengajar lebih menekankan pada bagaimana mengajarkan agama dan bagaimana mengajarkan tentang agama.

\section{Daítar Pustaka}

Abdullah, Amin. Pendidikan Agama Era Multi Kultural Multi Religius. Jakarta: PSAP, 2005.

Agus, Bustanuddin. Agama Dalam Kehdupan Manusia Pengantar Antropologi Agama. Jakarta: Raja Grafindo Persada, 2006.

al-Maraghi, Ahmad Musthafa. Tafsir Al-Maraghi, terj. Bahrun Abubakar. Semarang: Thoha Putra, 1993.

Baidhawy, Zakiyuddin. Pendidikan Agama Berwawasan Multikultural. Jakarta: Erlangga, 2005.

Departemen Agama RI. Al-Qur'an dan Terjemahnya. Bandung: J-Art, 2005. 
Faidhani, Achmad. "Konsepsi Al-Qur'an Tentang Tasamuh (Toleransi) dan Implementasinya Terhadap Pendidikan Islam." Skripsi. Program S-1 Fakultas Tarbiyah IAIN Walisongo, 2006.

Fanani, Ahwan. "Hubungan Antar Umat Beragama dalam Perspektif Lembaga Organisasi Keagamaan (Islam) Jawa Tengah." PUSLIT IAIN Walisongo, 2010.

Hamuza, Hijriyah. "Mencermati Makna Ajaran Muhammad Solusi Problem Ummah Masa Kini." Edukasi, Vol. VI, No 1, Juni 2009.

Hari, Cecep Syamsul \& Tholib Anis. Ringkasan Shahih al-Bukhari. Bandung: Mizan, 2000.

Idi, Abdullah \& Toto Suharto. Revitalisasi Pendidikan Islam. Yogyakarta: Tiara Wacana, 2006.

Ilhami, Herman. "Pendidikan Pluralisme Studi Kasus Integrated Curriculum di SLTP Madania Bogor." Skripsi. Fakultas Tarbiyah IAIN Walisongo, 2008.

Junaedi, Mahfud. Ilmu Pendidikan Islam Filsafat dan Pengembangan. Semarang: Rasail, 2010.

Ma’arif, Syamsul. Pendidikan Pluralisme di Indonesia. Yogyakarta: Logung Pustaka, 2005.

Moleong, Lexi J. Metodologi Penelitian Kualitatif. Bandung: PT. Remaja Rosdakarya, 1993.

Muhammad, Husein. Mengaji Pluralisme kepada Mahaguru Pencerahan. Bandung: Mizan, 2011.

Mukhtar. Desain Pembelajaran Pendidikan Agama Islam. Jakarta: IKAPI, 2003.

Mustholih, Achmad. "Konsep Pendidikan Pluralisme Menurut Abdurrahman Wahid dalam Perspektif Pendidikan Islam." Skripsi. Fakultas Tarbiyah IAIN Walisongo, 2011.

Naim, Ngainun \& Achmad Syauqi. Pendidikan Multikultural Konsep dan Aplikasi. Yogyakarta: ar-Ruz Media, 2008. 
Nawawi, Hadari. Metode Penelitian Bidang Sosial. Yogyakarta: Gadjah Mada Uneversity Press, 1998.

Peraturan Menteri Pendidikan Nasional Nomor 23 Tahun 2006 Tanggal 23 Mei 2006.

Quthb, Sayyid. Fi Dzilal al-Qur'an. terj. As’ad Yasin. Cet. I. Jakarta: Gema Insani, 2000.

Shihab, M. Quraish. Tafsir al-Misbah Pesan, Kesan, dan Keserasian alQuran. Cet. I. Jakarta: Lentera Hati, 2005.

SM, Ismail. Strategi Pembelajaran PAI Berbasis PAIKEM. Semarang: Rasail, 2009.

Sugiyono. Metode Penelitian Pendidikan: Pendidikan Kuantitatif, Kualitatif dan R \& D. Bandung: Alfa Beta, 2011.

Syarbini, Amirulloh. Al-Quran dan Kerukunan Hidup Umat Beragama. Bandung: Quanta, 2011.

Thoha, Anis Malik. Tren Pluralisme Agama: Tinjauan Kritis. Jakarta: Perspektif, 2005.

Thoha, Chabib. Kapita Selekta Pendidikan Islam. Yogyakarta: Pustaka Pelajar, 1996.

UUD 1945 Pasal 29Aayat 2.

Yaqin, Ainul. Pendidikan Multikultural. Yogyakarta: Pilar Media, 2005.

Zuriah, Nurul. Metodologi Penelitian Sosial dan Pendidikan: Antara Teori dan Praktik. Jakarta: PT. Bumi Aksara, 2006. 